\title{
Greg Kuzma
}

\section{The Search for the Beethoven A-minor String QuARTET}

I do not know anything about music except that I love it. I think that I would rather not know about it, even though I make some effort to try to find language for explaining it. People will say to me to take a course in music appreciation. Or Jerry Costanzo, a few weeks ago, confessed that that was the one course he did not take at Harvard, but had a marvelous time teaching himself about music. He just sent me a tape of "symphonies" by William Boyce, a contemporary of Handel's. I like them a lot, but I need to listen to them more. I find that after I listen thirty times the music begins to build its own audience in the cells of my ears. I begin to become addicted to the thing that it is, no matter how strange that thing may first have seemed.

I don't want to know ABOUT music. Just as I don't want to know about Sylvia Plath. I love Sylvia Plath, but I don't love her. I love her work, or rather I love certain poems of hers. The new biography of hers I started a couple days ago didn't work for me at all. It was then I realized how much reading is not at all a passive art. I thought it would be nice, now that the semester is over, and I can read something besides student poems, that I would read a good book, or just lie on the couch and let somebody else do the work. But it wasn't like that at all. It was like going on a cross-country trip and letting somebody else drive, and you having to sit there in the passenger seat and watch the whole thing happen, outraged and frightened and objecting the whole time. Until it becomes clear that it's far too exhausting to let somebody else drive you, and much easier if you do the driving yourself. I love Delmore's great joke- "Rahv drove until I was exhausted, and then I drove."

I'm not immune to talk about music, and I seek it. But I've never found it. I talked to Larry Lusk, a few months ago, about Beethoven, and he quick sent over to me the book the University did back in the seventies for the bicentennial of Beethoven's birth, where all the major piano sonatas were performed on campus over a few months, and 
Larry wrote liner notes for each one. I've tried to read them a few times, and every time bail out. They are very technical, done entirely in musical terms, each and every one a mystery to me. I find it especially frustrating to have one sonata described that is an absolutely ravishingly beautiful sonata, but not to be able to discern this from the text. And to have, similarly, another sonata described, which is, to my taste, a flat and lifeless one, and not have that be mentioned at all in the text. And I can only conclude that the language by which we would hope to know them is incredibly useless if it cannot distinguish one from another. A friend of mine did a book on Robert Frost a few years ago, and he wrote on every poem, treating the poems we read only once and never read again with the same seriousness as he treated "Birches" or "Hyla Brook." It was like having a couple hundred children, and not allowing yourself to discriminate. It was the longest book I ever read!

What I am interested in is beauty. Pure and simple. I want to be in the presence of beauty. I want to write beautiful poems, and I want to read beautiful poems. I want to see movies which are beautiful, and I cannot sit still to watch something not beautiful. When I read the Plath biography it was obvious that her life was not beautiful, and I did not want to hear any more about how ugly it was. Or how confused she was. Or how awful various people were. It is the voice in her writing that is transcendent which draws me. I want to be in the presence of that voice, and perhaps to have the voice through long association lift me, raise me up toward some transcendence for myself. And perhaps to influence my own language that it also aspire similarly toward the transcendent.

What I like about music is that I do not need to know anything other than what I know now. It is the same for poetry. I do not need to be told anything except to pick up the poem and begin reading. All I need to know is that the poem is in English, and then I am able to read it. With music it is even better. I can listen to a piece written by someone who spoke only Russian, or someone who spoke only French, and I find no difficulty in the translation. It's not even clear to me that the one is written by a Frenchman and the other by a Russian. I am willing to be told what to listen for in the different periods and different collective visions of what music is supposed to do, but I am not inter- 
ested in that very much. I want instead the transcendent power of being spoken to by this beautiful music written yesterday or two hundred years ago. I want to be united in my humanity with the humanity of the composer. However disparate we might be in ideas, however dispirited we might become to know each other's shortcomings, it is the joy of communion I seek. I want to experience it.

There are some problems. Sometimes I will ask someone what her favorite piece is, and she will give me a copy, and I will listen to it and I will not connect to it. What do I do? So far I have discovered only one cure, and that is to listen to the piece over and over. Never, in effect, to give up hope for it or for myself. I like this as a possible solution because it is so entirely democratic, because it trusts the music and because it trusts the listener. And because, too, it leaves out the experts. This is good work, honest work. I like how I have to condition myself to the piece, and to become familiar, to force myself to become familiar. The parallels are obvious, how we must force ourselves to become familiar with the tones of voice others assume, or the visions they have, or their way of talking, or their styles. Or sometimes I can hear a piece and I will love it at once. I listened to Verdi highlights coming back in my car from a reading a month ago and there were some incredible things. I can almost sing them even now. Or I will put in the tape of Missa Solemnis, and drink coffee, and some time fifty miles down the road the coffee and the music begin to pump through my veins as if they were interchangeable. And the unexpressed and unfulfilled musician in me heard that music and loved it.

My goal, if I have one, is to love everything. I want to struggle, but I reserve hope that eventually I will surrender and I will melt into the music and become one with it. Just as in my poems I will someday write a poem which is itself and yet universal and universally a donor for love and joy. A poem that is pure joy. In the meantime I am on the lookout for stuff. People give me lists, and I remember a lot of them, and so when I am at Blockbuster Audio or some other place I see things that I can recognize. There is a tremendous variety to what exists. And yet, at the same time, there are days when it all seems to be the same. Where it all has the same intent, or the same shape. It's like the reaction I sometimes have to books of poems, how they are all alike, and might well have been written all by the same person. I have 
reached a point where I do not hear differences, I hear only harmonies. I hear not what tones or emphases separate us one from the other, but what common affections bind us. Even in the study of poets for a $\mathrm{PhD}$ exam, I find my impulse is to ask how these supposedly different poets might be joined together, not what makes them each and all unique and different.

I find myself excited by the names of the pieces. I like the name Missa Solemnis. I like the name Beethoven. I like the name Mozart, even just to say it. I like to see how Mozart wrote all these symphonies, and they are numbered, but they are often very different. I like my love for the choral part of the Ninth by Beethoven, and my neglect of the earlier movements, but then to have Robert Coleman come to Crete the other day and to talk about his great joy in hearing the first three movements of the Ninth, and how much he loves them. Now I will have to go back and listen to them.

I love the choral part of the Ninth. I heard that just a few months ago, and I could not believe it. I did not know how to talk about it. I just wanted to hear it again. And yet I find I cannot listen to it much because it is so intense it makes me very nervous. I found, at Wards Music Shoppe, a copy of the Zukerman version of Beethoven's Violin Concerto. At that time in my association with music I liked only piano music. Barb and I were listening to the popular piano sonatas by Beethoven, and Barb was practicing the slow movement of the "Pathetique." So we could go in the car and hear these brilliant pieces, and then come rushing home where Barb would fall to playing on our newly rebuilt piano. It was like falling into bed together. I was trying to simplify my task. I would love Beethoven. I would listen only to the sonatas. Then I heard about the "late" sonatas, how different they are. Bud Emile calls them "real handbusters." He seemed, as he told me, to be a little daunted by them. Was it something about their not repaying enough in return for the tremendous effort we have to give to them? (That's an idea I'll save for later.) I was frustrated there was so little classical music on cassette in Lincoln, but then some friend said go to Homer's in Omaha, at Orchard Plaza. I wrote down the names on a piece of paper, then lost them, then had to hunt around, then inquired of other people, and then maybe found the same friend who had to tell me all over again. I had been seeing in the stores many 
copies of the same things. I found that this started to bother me, because I was looking feverishly for the late piano sonatas. I had been at a party and Fred Link told me that the late sonatas are played best by a guy named Richard Good. I remembered that name. Then one day Mark and I went up to Homer's at Orchard Plaza. It took us a while to get there but we finally found it, and Mark went shopping for CDs. I went to the classical section, off in its own room, and my heart was pounding. What delights awaited me? What would I find? And was this to be a good selection, as everybody said? There, in plain sight, in the Beethoven section, two tapes bound together, the late piano sonatas played by Richard Good. I was ecstatic! They were very expensive. The price seemed part and parcel of the experience. What, did I expect this would be easy? This listening to music! I gave myself those tapes for Christmas this year, and wrapped them up with some other wonderful mysterious things, and they are still in their Christmas wrap. I am saving them for the day when I am sufficiently ready to hear them. Will that day ever come?

From the grave Hugh Luke has reached out and saved me. It was his copy of the Ninth, made on his cassette player off an album, which he had given me ten years ago, and which I had had on a shelf, and then found last year. One night I got it out and drank a bottle of wine and listened to the Ninth. I kept rushing to meet it, I kept trying to connect, but it was like trying to connect with wind or hold water in your hands. I was getting drunk. I listened to the first three movements, and then played the second side. There was the choral part. It was unbelievable. Even now I remember it. My sense of it that night was greater than any subsequent sense I have made for myself. It was love upon first hearing, and with each subsequent hearing there have been greater or lesser effects, a gradual familiarity, a gradual lessening of the newness and freshness of it, until, the last time I played it I did not really much listen to it. It was the hearing of it the first time that overwhelmed me, and it is that hearing that sustains me even now.

There is, of course, some systematic and orderly way to go about this. I can see a certain kind of person, someone in a music school somewhere, or, who, when faced with my enthusiasm, would propose a detailed and lengthy schedule of listening and reading. My enthusiasm would be, to him, like that of a young dog, a sort of puppy bois- 
terousness, a sort of falling-over-my-own-feet kind of thing. The best thing for me is to try to cool off somewhere, or learn as quickly as possible how stupid I am, how crude my efforts at expressing my affections. And I will be given a program, sort of a twelve-step program, in order that I become more responsible for myself. I'm not interested. These pieces of music are instead to be acquired like contraband. I live on rumors. I exaggerate the difficulties, or I minimize them. I talk to strangers at parties, and invariably the topics turn to music. I have learned some truly amazing things, not facts, but affections, dreams of the human heart. At Barb's class reunion I asked a friend of hers from thirty years ago what he'd want to hear as he lay dying, and he told me. It was the Ninth! He was serious. We both were. Or I learn what there is and where it's available late at night in the most unlikely places, standing drunk at parties, for instance, to wander into a room and there find the ubiquitous Fred Link talking, and sneak over and listen in. We act inconspicuous, we're not even talking about music, but then I'll try to put him in the mood. Maybe I mention Mozart and try to maneuver Fred into saying something extravagant about him, and he usually does. Or then there was that incredible night at Biljana's, when the search for the A-minor began. It was about a year ago. I said I had heard something about the late string quartets, I think I read a little in the Solomon book, and then he said that thing which changed my life. He said "Beethoven's A-minor is one of the most beautiful pieces of music ever written."

All the way back in the car I dreamt of it. What is it like, where would I find it, and would I understand it, would I be worthy of it? How would I find it, and is it available in cassette? One of the major drawbacks here is that I do not own a CD player. I have only cassettes. Having a CD would simplify everything. I would only have to go in and plock down fifteen bucks and I could have the A-minor, maybe any of a dozen recordings, mixed in with other incredible quartets. I remember going into Best Buy and checking out the Beethoven stuff. Usually in a music store the classical cassettes occupy a small section of shelves. They're the least sought-after items in the store. Only once have I ever seen another human being looking with me in the classical cassettes! Usually there are seven or eight shelves, and most of them taken up by tapes of Pavarotti, or the other tenors, who 
are very popular now. For Beethoven, if I'm lucky, I'll find recordings of the symphonies, though not all of them. There will be four or five of the Fifth, and maybe three or four of the Ninth, maybe the Pastoral, a little piano music, and that's it. At Wards once I found the violin concerto and I played it a couple hundred times. The cassette cost $\$ 2.99$. At Best Buy, on the other hand, that day I went there, the Beethoven section went down a whole row. There were big plastic marker cards to designate the kinds of stuff. There were probably a hundred CDs of the piano sonatas and when I got to the string quartets there were cards that said THE EARLY STRING QUARTETS, THE MIDDLE STRING QUARTETS, and THE LATE STRING QUARTETS. I was stunned.

When you only have a cassette player it's like being in the antique business, looking for maybe old prints, or, as my father did, back in the forties, looking for old guns. Every auction might have its odd gun or two, which he'd look over and maybe bid on. Or going to Otto Schneible's farm, which was packed with antiques, barns full of stuff; there'd be an old gun Ott would have bought. Always the faint smell of cow manure in the air, which to this day I continue to associate weirdly with old furniture. My father shopped basically without money, which made it very challenging. What he did, I realize, is what I'm doing. Someone who has only a cassette player is a poorman in today's music world. At Best Buy packets of the Late Quartets, with maybe two CDs, are selling for $\$ 39$. Other things for more! I'm trying to get the same stuff for $\$ 3$, or $\$ 4$. RCA has an "essential classics" line of 100 tapes, and maybe one of these will contain the A-minor. You can be just as interested as anybody, or you can be, as in my case, maybe even more interested than most people. But if you are like my father and me you have two simultaneously contradictory goals, you want it but you want it cheap. At today's CD prices, what I want to pay is next to nothing. I want it "for nothing." I'm just like my father.

The passion for quality runs in many people, but the passion for something free or cheap, which is yet a good thing, is common too. We just had a visitor who talked about antiques a lot, and all the stories were about getting something that was fantastic but buying it from somebody who does not know what they have. No regrets, no remorse, no feeling that maybe you took advantage of the other per- 
son. My father did that too, and he did not look back. Our visitor was well-to-do, and I guess intends to stay that way. You buy it for $\$ 50$, he says, and then turn around the next day and sell it for $\$ 1500$. Nobody is the wiser. When I heard those stories I wondered if that was what I was doing, trying to steal something. Here are all these unsuspecting kids just out of college, starting their six-month job at Best Buy, or working their way through college, who maybe never had music appreciation, or probably don't even like classical music. Highbrow stuff. And there I am grabbing it up by the armful, at $\$ 3$ a tape. It's criminal, isn't it?

I'm building a rather huge collection. It's totally haphazard, I have no rhyme or reason to it, I just get stuff, then start listening, then, before I've really figured it out, I've got something else that interests me. I rely on impulse, impulse in the buying, and impulse in the listening. I listen, but for what am I listening, I do not know. I want some semblance of order or system, but there isn't one. I'm totally indiscriminate. I don't want to impose any outside constraints. I don't want to relegate myself only to early Italian Baroque, for instance. I want to engage everything.

To a great extent, I realize, this passion for music is a metaphor, a symbol, for my passion for the world. I cannot have the world, I do not have the money, nor the time left. I am fifty years old. But with the music I can have everything, or I can try to have everything. Maybe every collection people make is an attempt to address the full world but in miniature or in some manageable cross section. I cannot do everything. I cannot write music, I cannot paint, I will not be an actor, I will not be a politician or a mountain climber. But I can feel what it is to be alive in the music, I can feel the feelings others felt, what it is to be human, to dream, to love, to storm in anger or passion, to quest, to search, to stand in awe. All I have to do is find the tapes.

Out there somewhere is the A-minor Quartet, in cassette. It's maybe lying on a discount table at a music store, or maybe it's actually in place on one of the shelves, right next to a copy of the great Serkin Sonatas, which I have and love. But just another copy of what, really, there's no real call for anymore. I did order a tape of the quartets, but they're Opus 59, and I want the later quartets. Still I had to have it. In the whole computer listings at the music store it was the only cassette 
available for any of the quartets. They ordered it for me, and it came in, and I got it. And I did not like it. I listened to it a lot, but I couldn't figure it out. It just isn't beautiful, it isn't melodic, or something. It was a lot of work. Maybe I need that two-year course, after all? I wondered. I still take it around with me. It's a tough one! I try to play it after an especially easy time with Chopin, some pieces I already know, just to get my confidence up, or when I'm in a really good mood, then I'll put it in, and maybe I can get through five or six minutes of it, where I think I'm really hearing it, the shape of it, some masterful design that begins to emerge, and then I break under the tremendous strain, and the piece goes opaque and lifeless. It becomes pure noise.

Maybe the A-minor will be like that. Maybe I will not live long enough to understand the A-minor? It's a sobering thought. Maybe to appreciate the A-minor you need to start training yourself young. Maybe play the violin for ten years, or try to write some violin music. I don't know. But I want my chance. Some day, I think it will be when I least expect it, maybe when I'm hot on the trail of some Vivaldi flute concertos, which have taken me over, I'll have my hand on it and not even know it, there on the shelf, as I was just breezing along, running my hand over the cassette boxes, touching base as it were, and it will be there. That, I think, will be my lucky day! 